\title{
Ordenamento territorial do Município de Visconde do Rio Branco
}

\author{
Ordering territory of the Municipality of Visconde do Rio Branco \\ Ordenación territorial del Municipio de Visconde do Rio Branco
}

Recebido: 05/02/2021 | Revisado: 12/02/2021 | Aceito: 17/02/2021 | Publicado: 27/02/2021

\author{
Lucas Pinheiro de Paula \\ ORCID: https://orcid.org/0000-0002-7391-2866 \\ Universidade Federal de Juiz de Fora, Brasil \\ E-mail: lucas13pinheiro@gmail.com \\ Ricardo Tavares Zaidan \\ ORCID: https://orcid.org/0000-0002-5033-993X \\ Universidade Federal de Juiz de Fora, Brasil \\ E-mail: ricardo.zaidan@ufjf.edu.br \\ Angelo Alves Carrara \\ ORCID: https://orcid.org/0000-0002-7807-2632 \\ Universidade Federal de Juiz de Fora, Brasil \\ E-mail: angelo.carrara@gmail.com
}

\begin{abstract}
Resumo
O Estado brasileiro enfrentou ao longo do século XIX o desafio de ordenar o território no interior das províncias. A constituição político-administrativa se apresentava de uma forma muito mais complexa como conhecemos atualmente. Se os municípios atualmente são subdivididos apenas em distritos, anteriormente os poderes políticos, judiciários e eclesiásticos participavam do ordenamento territorial e diferentes categorias se sobrepunham gerando um complexo ordenamento territorial. A cidade de Visconde do Rio Branco, localizada no sudeste de Minas Gerais tem seu processo de formação inserido dentro desse contexto. Quando ainda povoado denominava-se Aldeia do Xopotó dos Coroados, e o município foi criado somente em 1839 após ser desmembrado de Pomba com a denominação de Vila de São João Batista do Presídio. O município do Presídio tem um papel importante na consolidação da territorialidade da porção central da zona da mata mineira, do seu território originaram-se 49 municípios. Nesse sentido o objetivo dessa pesquisa é discutir a evolução do ordenamento territorial do município de Visconde do Rio Branco, explicando as diferentes categorias que fizeram parte do ordenamento territorial do município ao longo do século XIX e XX. A metodologia adotada fundamentou-se em pesquisas bibliográficas e geoprocessamento aplicado a cartografia histórica. Espera-se que a pesquisa possa contribuir com informações e materiais cartográficos que enriqueçam a geografia-histórica dos municípios de Visconde do Rio Branco e também dos municípios que se desmembraram de seu território original.
\end{abstract}

Palavras-chave: Ordenamento territorial; Cartografia histórica; Visconde do Rio Branco.

\begin{abstract}
The Brazilian State faced throughout the 19th century the challenge of ordering the territory in the interior of the provinces. The political-administrative constitution was presented in a much more complex way as we know it today. If the municipalities are currently subdivided only into districts, previously political, judicial and ecclesiastical powers participated in the territorial ordering and different categories overlapped, generating a complex territorial ordering. The city of Visconde do Rio Branco, located in the southeast of Minas Gerais has its formation process inserted within this context. When it was still populated, it was called Aldeia do Xopotó dos Coroados, and the municipality was created only in 1839 after being dismembered from Pomba under the name of Vila de São João Batista do Presídio. The municipality of Presídio has an important role in consolidating the territoriality of the central portion of the area of the Minas Gerais forest, from its territory 49 municipalities originated. In this sense, the objective of this research is to discuss the evolution of the territorial ordering of the municipality of Visconde do Rio Branco, explaining the different categories that were part of the territorial ordering of the municipality throughout the 19th and 20th century. The methodology adopted was based on bibliographic research and geoprocessing applied to historical cartography. It is hoped that the research can contribute with information and cartographic materials that enrich the historical geography of the municipalities of Visconde do Rio Branco and also of the municipalities that dismembered from their original territory.
\end{abstract}

Keywords: Ordering territory; Historical cartography; Visconde do Rio Branco.

\section{Resumen}

El Estado brasileño enfrentó el desafío de ordenar el territorio dentro de las provincias a lo largo del siglo XIX. La constitución político-administrativa se presentó de una manera mucho más compleja tal como la conocemos hoy. Si en 
la actualidad los municipios se subdividen únicamente en distritos, anteriormente los poderes político, judicial y eclesiástico participaban en el ordenamiento territorial y se superponían distintas categorías, generando un ordenamiento territorial complejo. La ciudad de Visconde do Rio Branco, ubicada en el sureste de Minas Gerais tiene su proceso de formación insertado en este contexto. Cuando todavía estaba poblado se llamaba Aldeia do Xopotó dos Coroados, y el municipio se creó solo en 1839 después de ser separado de Pomba con el nombre de Vila de São João Batista do Presídio. El municipio de Presídio tiene un papel importante en la consolidación de la territorialidad de la porción central del área forestal de Minas Gerais, de su territorio se originaron 49 municipios. En este sentido, el objetivo de esta investigación es discutir la evolución del ordenamiento territorial del municipio de Visconde do Rio Branco, explicando las diferentes categorías que formaron parte del ordenamiento territorial del municipio a lo largo de los siglos XIX y XX. La metodología adoptada se basó en la investigación bibliográfica y el geoprocesamiento aplicado a la cartografía histórica. Se espera que la investigación pueda contribuir con información y materiales cartográficos que enriquezcan la geografía histórica de los municipios de Visconde do Rio Branco y también de los municipios que se han desmembrado de su territorio original.

Palabras clave: Ordenar território; Cartografía histórica; Visconde do Rio Branco.

\section{Introdução}

A primeira divisão administrativa no estado de Minas Gerais, ocorreu da criação das três primeiras vilas no ano de 1711 pelo governador Antônio Albuquerque Coelho de Carvalho, sendo elas: Ribeirão do Carmo, atualmente Mariana, Vila Rica, atualmente Ouro Preto e Vila Real de Nossa Senhora da Conceição de Sabará, atualmente Sabará. Os municípios subsequentes que foram criados ao longo dos anos surgiram do desmembramento das primeiras vilas de Minas Gerais (Costa, 1997).

O aumento no número de municípios ao longo dos anos, segundo Reis et al. (2011), ocorreu devido à expansão das fronteiras econômica e demográfica, pela motivação a descentralização política-administrativa nos períodos de liberalização política, e também foi motivado pela possibilidade de maior arrecadação de impostos através da instalação de novas partições públicas.

Nos dias atuais, os critérios para a criação de um novo município são mais rigorosos. Somente ocorre mediante a estudos de viabilidade municipal, análise do tamanho da população, viabilidade financeira e de infraestrutura, além de plebiscito envolvendo a população dos municípios envolvidos. Os desmembramentos são realizados por lei estadual, dentro de período determinado por lei complementar federal, como encontra definido a partir da Emenda Constitucional $\mathrm{n}^{\circ} 15$ em seu artigo 18 da Constituição Federal. Porém essas definições são recentes, durante o século XIX e até mesmo início do século XX, não só os critérios de criação de novos municípios eram distintos, como a própria organização do território das províncias se subdividiam em uma extensa e complexa lista de diferentes categorias.

Uma análise da organização do território demonstra que se atualmente a subdivisão do Estado se dá em municípios e distritos, em períodos anteriores a organização se estendia a outras diversas categorias. Durante o século XIX, as categorias que demarcavam o território da província criavam uma complexa organização do território que se sobrepunha entre o poder administrativo, eclesiástico e judiciário (Carrara \& Machado, 2020).

A história política administrativa e territorial de qualquer município é descrita utilizando diversos conceitos administrativos, eclesiásticos e judiciários. Enquanto alguns conceitos utilizados no passado já não existem na organização do território atualmente, outros ainda se fazem presentes. Registro, Freguesia, Termo, Paróquia, Distrito, Vila, Cidade e Comarca são exemplos de conceitos que explicam e/ou explicavam o ordenamento territorial.

Para se ter uma ideia da complexidade da organização do território no interior da província, Carrara \& Machado (2020) evidenciam que até mesmo o vocábulo município apresentava significado distinto do atual. Ou seja, o município como uma base territorial abrangida pelo poder administrativo da cidade sede somente adquire tal sentido a partir da Lei Geral de $1^{\circ}$ de outubro de 1828. Portanto, o vocabulário moderno utilizado na divisão territorial do Estado foi alterado ao longo do tempo, até se estabilizar na categoria atual. 
Logo, diante do cenário de crescimento do número de municípios, de diferentes categorias sobrepondo o ordenamento territorial e critérios indefinidos para a criação de novos municípios, identifica-se um cenário desafiador para o Estado brasileiro principalmente no século XIX na organização do território.

$\mathrm{O}$ atual município de Visconde do Rio Branco estava inserido neste contexto, sua origem está ligada ao surgimento do povoado em uma conjuntura de ocupação da zona da mata mineira para introduzir agropecuária, realizar extração de minerais e vegetais e colocar em prática a política de aldeamento dos índios. O povoado foi consolidado em 1787, com a construção da sua primeira capela, passando a classificar a localidade como arraial. Em 1810 o arraial foi elevado à categoria de freguesia, com a construção da sua paróquia. Em 1839 a freguesia ganhou o status de vila, e finalmente o município foi criado, naquele período com a denominação de São João Batista do Presídio. Porém o ordenamento territorial do município naquele período se apresentava de uma maneira confusa.

Por conseguinte, o objetivo do presente trabalho é discutir a evolução do ordenamento territorial do município de Visconde do Rio Branco, explicando as diferentes categorias que fizeram parte do ordenamento territorial do município ao longo do século XIX e XX.

Para atingir o objetivo, utiliza-se de pesquisas bibliográficas que destacam a geografia histórica do município de Visconde do Rio Branco e tratam das diferentes categorias que ordenavam o território do estado de Minas Gerais. Além das fontes bibliográficas, o presente trabalho utiliza como fonte mapas históricos.

O campo de pesquisa que estuda os mapas históricos e antigos denomina-se Cartografia Histórica, e proporciona ao pesquisador o acesso a novas informações além das fontes textuais. Antes de se retirar qualquer informação dos produtos cartográficos históricos, deve-se realizar o tratamento desses mapas, visto que esses foram elaborados utilizando técnicas antigas, o que significa, que esses mapas não apresentam a mesma precisão espacial que os produtos cartográficos atuais.

Nessa perspectiva, o presente trabalho utilizará das interfaces do geoprocessamento, com aplicação de técnicas de georreferenciamento e vetorização como meio para utilização das informações presentes no mapa histórico.

O mapa histórico que será utilizado foi elaborado por João José da Silva Theodoro em 1847. O mapa foi realizado através de um pedido do então presidente da província de Minas Gerais Quintiliano José da Silva. O ofício para elaboração do mapa foi emitido em 12 de junho de 1845, e o mapeamento objetivava examinar os limites da província de Minas Gerais com as províncias do Rio de Janeiro e Espírito Santo, sendo a primeira pelo trecho de Campos, e a segunda pelo trecho de Itapemirim. Para verificar os limites com as demais províncias, foi necessário delimitar o território dos municípios que se estendiam até a divisa. Nessa perspectiva que o mapa em questão delimita os municípios de São João Nepomuceno, Presídio e Pomba. A partir do geoprocessamento aplicado a cartografia histórica, pretende representar a organização espacial da Vila de São João Batista do Presídio em 1847 a partir da interpretação e da descrição geográfica e cartográfica de João José da Silva Theodoro.

O trabalho se justifica a medida que o estudo ordenamento territorial da vila de São João Batista do Presídio diz respeito a consolidação da territorialidade da porção central da zona da mata mineira, já que a partir do território do município de Visconde do Rio Branco originaram-se outros 49 municípios. Além disso, o ordenamento territorial de Visconde do Rio Branco está inserido no contexto do estado mineiro, logo abordar a sua evolução é também tratar da história de organização dos municípios mineiros. Por fim, estre trabalho aborda metodologia que busca associar cartografia histórica e geoprocessamento, capaz de gerar produtos cartográficos que contribuem com a geografia histórica do município de Visconde do Rio Branco.

\section{Metodologia}

Em síntese, a pesquisa desenvolvida nesse trabalho se estruturou metodologicamente como uma pesquisa laboratorial 
baseada em levantamento de dados bibliográficos e processamento de dados cartográficos para elaboração de mapas temáticos.

\subsection{Ordenamento territorial}

Para trabalhar com ordenamento territorial do município de Visconde do Rio Branco, é importante trazer as bases teóricas que guiaram o presente trabalho. A expressão ordenamento territorial se remete a concepção de dois conceitos: ordem e território.

A expressão ordem, no dicionário, recebe uma gama de diferentes significados, entre eles o sinônimo de organização, ordenação, arrumação, disciplina, arranjo, lei, estrutura, administração e regularidade. Através dos diferentes significados atribuídos a expressão ordem, podemos perceber que este carrega uma relevante dose de subjetividade. Desta maneira, Machado (2012), expõe que um território dependendo de quem o observa pode se encontrar ordenado ou desordenado, evidenciado o grau de subjetividade da expressão. Portanto, ordenar revela a particularidade do ser humano de colocar as coisas no lugar que ele considera adequado.

A compreensão do ordenamento territorial, passa pela necessidade de avaliar o conceito de território. O conceito de território possui uma relação muito forte com a ideia de domínio de uma determinada área, por essa questão o território é fortemente relacionado com “poder”. O poder exercido em uma área pode ocorrer através do poder público, estatal ou até mesmo de grandes empresas que ignoram fronteiras políticas (Andrade, 2004).

Já o ordenamento territorial diferentemente do conceito do território é um conceito recente que se encontra em processo de construção. Por vezes o conceito aparece como ciência, ora como política ou então como técnica administrativa, portanto ainda não se trata de um conceito claro (Machado, 2012).

O processo de ordenar o território significa identificar, distribuir, organizar e regular as atividades humanas no território, de acordo com determinados critérios. Logo, o ordenamento territorial constitui um processo que tem por objetivo orientar a ação do homem na superfície terrestre (Orea, 2008).

Portanto, ficará visível ao longo deste trabalho a forte relação com as passagens de Raffestin, em que ele concede ao território uma evidência político-administrativa, e um espaço delimitado por uma ordem jurídica e/ou política. Raffestin coloca também que o espaço pode ser delimitado por diferentes ordens, como a jurídica e a política, e neste trabalho também a eclesiástica (Raffestin, 1993).

Haesbaert expõe que o território também é múltiplo, diverso e complexo, logo, é contrário à ideia de território "unifuncional", que atualmente é reproduzida pela figura do Estado moderno, não admitindo multiplicidade/sobreposição de jurisdições e/ou de territorialidades. O ordenamento territorial dos municípios no Brasil também vai de encontro com o que Haesbaert expõe sobre o fato do território não ser unifuncional, e sim múltiplo, já que é possível notar uma sobreposição de jurisdições e territorialidades no espaço que em muitos casos se confundem (Haesbaert, 2007).

Para o levantamento dos dados bibliográficos foram levantados dados legais, referentes as leis publicadas sobre ordenamento territorial, e também foi realizada uma pesquisa utilizando outros autores para compreender o processo de ordenamento territorial em Minas Gerais e os significados das diferentes categorias que ordenavam o território.

A respeito dos dados legais, consistiu inicialmente em um levantamento realizado no SIAAPM (Sistema Integrado de Acesso ao Arquivo Público Mineiro), nele constam as Leis Mineiras de 1835 até 1889. Para o período anterior utilizou-se como fonte as Leis do Império, e posteriormente a 1889 o levantamento foi realizado no site da Assembleia Legislativa de Minas Gerais. Para o levantamento utilizou-se o sistema de pesquisa adotando os diferentes topônimos de Visconde do Rio Branco para acessar todas as leis relacionadas ao ordenamento da área de estudo.

Referente ao ordenamento territorial de Minas Gerais foram utilizados os principais autores do tema como: Fonseca (2011), Marx (1991), Mata (2002) e principalmente Martins e Soares (2016) com sua obra Comarcas de Minas que foi 
realizada para preservar a história mineira.

\subsection{Cartografia História}

No campo da cartografia, os pesquisadores viram uma nova possibilidade de realizar diversos trabalhos e estudos com os mapas históricos, contribuindo de forma direta para um impulso no que se refere ao desenvolvimento de um de seus diversos ramos, a Cartografia Histórica. Rossato (2006) a define como:

Uma especialidade da Cartografia que tem como enfoque as características temporais das representações cartográficas, assim como seu estudo, construção e utilização, e complementa que trabalhos que 'utilizam mapas antigos e/ou históricos como fontes de informações' e/ou 'constroem mapas históricos'. (Rossato, 2006 apud Martins \& Silva, 2014, p. 493).

A Cartografia Histórica, possibilita trabalhar com diversas fontes de dados históricos, fontes que muitas vezes só se encontram em produtos cartográficos. Nessa perspectiva, a Cartografia Histórica irá fomentar com dados e informações principalmente os estudos dentro do campo da Geografia Histórica.

O presente trabalho adota procedimentos metodológicos que alinham o campo da Cartografia Histórica com o geoprocessamento. $\mathrm{O}$ desenvolvimento recente nas últimas décadas da informática, possibilitou com que o geoprocessamento se afirmasse como um importante instrumento para estudos e trabalhos voltados a análise espacial. No campo da Cartografia Histórica, o geoprocessamento pode auxiliar os pesquisadores a identificarem os erros contidos nos mapas produzidos em tempos remotos, também possibilita recriar ou modificar os mapas históricos de acordo com a necessidade do pesquisador e a extrair informações para construir uma base de dados.

Os procedimentos metodológicos foram inspirados nos autores Colavite e Barros (2009), Castro (2017) e Corrêa (2008), referências em estudos que alinham o geoprocessamento a Cartografia Histórica no Brasil.

Castro (2017) desenvolveu uma metodologia para responder questionamentos que surgem nos trabalhos com mapas históricos, como: data do mapeamento, nome do autor, técnicas empregadas, desvios entre outras questões. Diante dessa perspectiva, construiu um procedimento metodológico dividido em três etapas: "inventário de fontes" - que consiste em catalogar, digitalizar e referenciar as informações; "processo" - representar e analisar os mapas e textos; "produto" - georreferenciar, vetorizar e tratar as informações espaciais.

O trabalho de Colavite e Barros (2009), realizou a demarcação do Caminho de Peabiru, que se trata de uma rota précolombiana que atravessava o estado Paranaense e teve importante participação na construção do estado. Para realizar a demarcação do caminho, os autores utilizaram o mapa antigo de 1952, elaborado por Reihnard Maack. O objetivo do trabalho é espacializar o Caminho do Peabiru em um mapa atual. Para isso, através do geoprocessamento o mapa de 1952 foi sobreposto sobre um mapa atual de mesma área, foram realizados ajustes na escala do mapa antigo, e através desse processamento de dados obtiveram uma base inicial para dar prosseguimento a demarcação do Caminho.

Por fim, dentre os estudos que buscam associar cartografia histórica e geoprocessamento, destaca-se a tese desenvolvida por Douglas Corbari Corrêa, nomeada Cartografia Histórica do Rio de Janeiro: Reconstituição Espaço-Temporal do Centro da Cidade. Em seu trabalho, publicado no ano de 2008, Corrêa, com o objetivo de comparar o centro da cidade do Rio de Janeiro em 1700 e 2000, utilizou mapas que representavam a sua área de estudo dentro do seu período histórico. Os procedimentos adotados por Corrêa (2008) se estabeleceram da seguinte forma: inicialmente, o autor definiu o recorte temporal de seu trabalho e fez um levantamento de todos os mapas que se adequavam dentro desse período histórico. Posteriormente realizou a pré-seleção para identificar os mapas que continham informações pertinentes. Após a pré-seleção todos os mapas foram transferidos para o meio digital. A etapa de processamento dos mapas, foi realizada o georreferenciamento seguido da 
vetorização. Para georreferenciar o mapa adotou-se o método master/slave, onde utiliza-se uma imagem de coordenadas conhecidas (master), e associa-se a imagem sem coordenadas definidas através de pontos incomuns entre elas. Após os mapas georreferenciados, todos os mapas foram vetorizados, o que tornou possível colocar em um mesmo banco de dados as informações dos mapas dos diferentes períodos, facilitando assim a comparação e a criação dos mapas de sínteses para ajudar na análise das mudanças que ocorreram no centro urbano do Rio de Janeiro.

A base metodológica apresentada foi utilizada para a definição dos procedimentos metodológicos do presente trabalho. Por agora apresenta-se as diferentes etapas para a construção do trabalho.

Inicialmente foram selecionadas as cartas topográficas que seriam necessárias para cobrir a mesma extensão da superfície territorial que o mapa antigo. Para a seleção considerou-se a menor escala disponível (1:50.000) para cobrir toda a área, tendo em vista a necessidade de maiores detalhes na representação. Abarcar toda a área representada no mapa antigo significou a seleção de um total de 41 cartas topográficas.

Tabela 1: Lista das cartas topográficas utilizadas para cobrir a extensão territorial do mapa antigo.

\begin{tabular}{|l|l|}
\hline Cartas topográficas utilizadas & Miraí (SF-23-X-D-II-2) \\
\hline Além Paraíba (SF-23-X-D-V-4) & Muriaé (SF-23-X-D-III-1), \\
\hline Anta (SF-23-Z-B-II-1) & Paiva (SF-23-X-D-I-3) \\
\hline Argirita (SF-23-X-D-V-1) & Palma (SF-23-X-D-III-3) \\
\hline Astolfo Dutra (SF-23-X-D-II-3) & Piranga (SF-23-X-B-IV-1) \\
\hline Cantagalo (SF-23-X-D-VI-3) & Ponto Firme (SF-23-X-B-IV-2) \\
\hline Carangola (SF-23-X-B-VI-2) & Porciúncula (SF-23-X-B-VI-4) \\
\hline Cataguases (SF-23-X-D-II-4) & Recreio (SF-23-X-D-VI-1) \\
\hline Divino de São Lourenço (SF-24-V-A-IV-2) & Rio Espera (SF-23-X-B-IV-3) \\
\hline Ervália (SF-23-X-B-V-4) & Rio Pomba (SF-23-X-D-I-4) \\
\hline Espera Feliz (SF-24-V-A-IV-1), & Santo Antônio de Pádua (SF-23-X-D-VI-2) \\
\hline Eugenópolis (SF-23-X-D-III-2) & São João Nepomuceno (SF-23-X-D-IV-2) \\
\hline Fervedouro (SF-23-X-B-VI-1) & São Miguel do Anta (SF-23-X-B-V-2) \\
\hline Guaçuí (SF-24-V-A-IV-4) & Sapucaia (SF-23-X-D-V-3) \\
\hline Juiz de Fora (SF-23-X-D-IV-1) & Senador Firmino (SF-23-X-B-IV-4) \\
\hline Leopoldina (SF-23-X-D-V-2), & Teixeiras (SF-23-X-B-V-1) \\
\hline Manhuaçu (SF-23-X-B-III-4) & Tocantins (SF-23-X-D-I-2) \\
\hline Manhumirim (SF-24-V-A-I-3) & Três Rios (SF-23-Z-B-I-2) \\
\hline Mar de Espanha (SF-23-X-D-IV-4) & Ubá (SF-23-X-D-II-1) \\
\hline Mercês (SF-23-X-D-I-1), & Viçosa (SF-23-X-B-V-3) \\
\hline Miracema (SF-23-X-D-III) & \\
\hline Miradouro (SF-23-X-B-VI-3) & \\
\hline
\end{tabular}

Fonte: Autores (2021).

A obtenção das cartas topográficas foi através do download no site do BDGEx (Banco de Dados Geográficos do Exército). O banco de dados do exército foi escolhido a medida que disponibiliza as cartas já georreferenciadas, com as coordenadas geográficas definidas. 
A utilização das cartas topográficas como base de dados ocorreu após as mesmas serem preparadas graficamente. Inicialmente retirou-se as informações que constam em suas bordas, como título, escala, orientação, legendas, projeção cartográfica e coordenadas. O recorte foi realizado através do software ArcGis, pela ferramenta de extração por máscara (ArcToolbox -> análise espacial -> extração -> extração por máscara). O recorte através dessa ferramenta funciona da seguinte forma: o software faz a leitura de um arquivo raster (carta topográfica), e utiliza um outro arquivo shapefile como máscara sobre a imagem raster para a realização da extração apenas da área de interesse.

No processo de extração, utilizou-se como máscara o shapefile do Mapa Índice Digital do IBGE. O Mapa Índice foi criado para servir de referência a respeito do mapeamento sistemático existente no país. O shapefile utilizado fornece o encarte entre as cartas topográficas em ambiente analógico, permitindo que este encarte seja utilizado como referência de extração para retirada das bordas das cartas.

$\mathrm{Na}$ continuidade dos procedimentos, as cartas topográficas por já se encontrarem georrferenciadas, apresentavam sistema de referência Datum WGS 1984 (World Geodetic System) e sistema geográfico. Na perspectiva de trabalhar com o mesmo sistema de referência em toda a base de dados, as cartas foram projetadas para o sistema SIRGAS 2000 (Sistema de Referência Geocêntrico para as Américas) que é o sistema de referência mais atual e oficial utilizado no Brasil desde fevereiro de 2015. A projeção foi realizada através do ArcGis, pelo do seguinte caminho: ArcToolbox -> Ferramenta de Gerenciamento de Dados -> Projeções e Transformações -> Raster -> Projetar Raster.

Após a projeção, o passo seguinte consistiu em unir todas as cartas topográficas formando um único arquivo raster capaz de abarcar toda a área de interesse. A união das cartas topográficas através da criação de um único mosaico facilitou o manuseio do arquivo.

A etapa subsequente incidiu em um trabalho investigativo. Inicialmente foram selecionados vilas ou cidades, freguesias, curatos e capelas presentes no mapa de 1847. Posteriormente todas essas localidades foram demarcadas na base cartográfica atual, utilizando como referência as cartas topográficas trabalhadas nas etapas anteriores.

Figura 1: Demarcação do então curato de São Sebastião do Feijão Crú (A) na base cartográfica atual (B). O Curato corresponde atualmente ao município de Leopoldina.
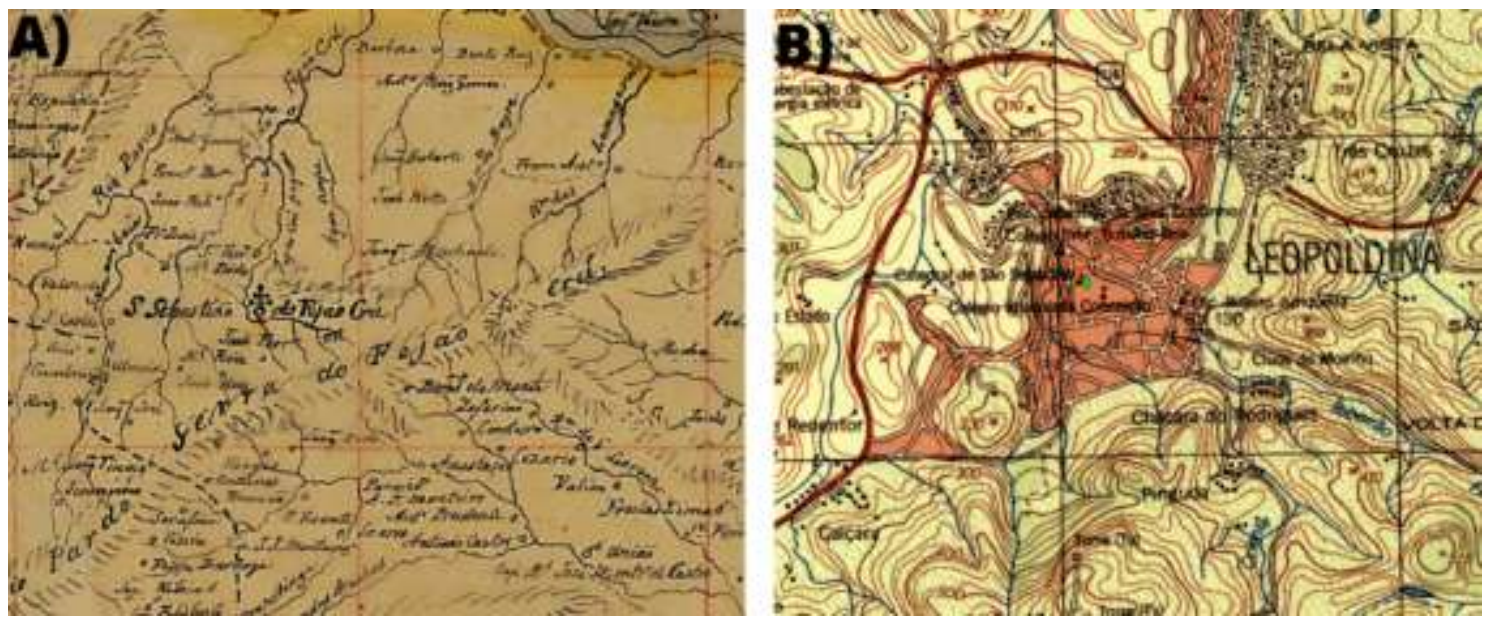

Fonte: Autores (2021).

A etapa seguinte consistiu no georreferenciamento dos produtos cartográficos. Essa técnica refere-se a associar o mapa a sua coordenada real na superfície terrestre, ou seja, posicioná-lo geograficamente. Nessa etapa adotou-se o procedimento master/slave, onde foi selecionado um mapa da mesma área com coordenadas já definidas para ser referência do 
mapa histórico. Os pontos de controle adotados para o georreferenciamento do mapa histórico consistiram nas vilas, freguesias, curatos e capelas.

Posteriormente foi realizado a vetorização do mapa. Essa técnica consiste em destacar determinada informação de interesse do mapa em detrimento das demais. Por exemplo, uma carta cartográfica contém diversas informações, como estradas, hidrografia, limites municipais e curvas de nível. A vetorização permite que se retire apenas o dado de interesse, podendo trabalhá-lo com outras informações através do geoprocessamento. Nessa perspectiva, com o mapa georreferenciado foi possível vetorizar os limites dos municípios de Visconde do Rio Branco, Rio Pomba e São João Nepomuceno sobre a perspectiva de João José da Silva Theodoro.

Figura 2: Fluxograma dos procedimentos metodológicos.

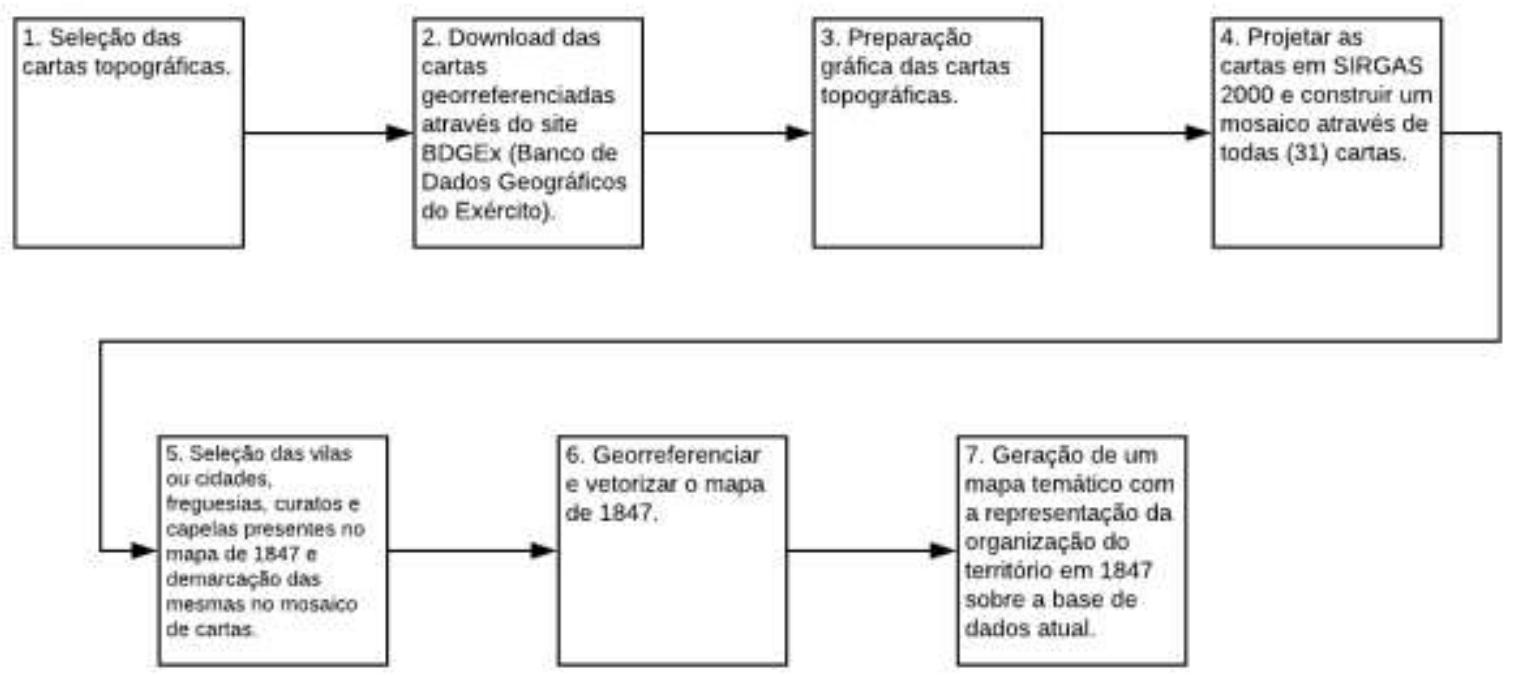

Fonte: Autores (2021).

\section{Resultados e Discussão}

$\mathrm{O}$ ordenamento territorial dos municípios brasileiros pode ser dividido em três momentos distintos. O primeiro momento se estende até o ano de 1828, mais precisamente até a publicação da Lei de $1^{\circ}$ de Outubro de 1828 , através desta lei que surge o vocábulo município no Brasil dentro da concepção atual do seu significado, modificando as estruturas da organização administrativa vigente. O segundo momento de 1828 até 1889, perpassa por um Brasil imperial, onde existiam três modelos de organização territorial: administrativo, eclesiástico e jurídico. O terceiro momento inicia-se com a instauração da república, que é marcado pela desvinculação da igreja e do estado, colocando fim a organização territorial pela perspectiva eclesiástica. 
Research, Society and Development, v. 10, n. 2, e50710212720, 2021

(CC BY 4.0) | ISSN 2525-3409 | DOI: http://dx.doi.org/10.33448/rsd-v10i2.12720

Figura 3: Diferentes categorias da história-político administrativa e territorial durante o século XIX.

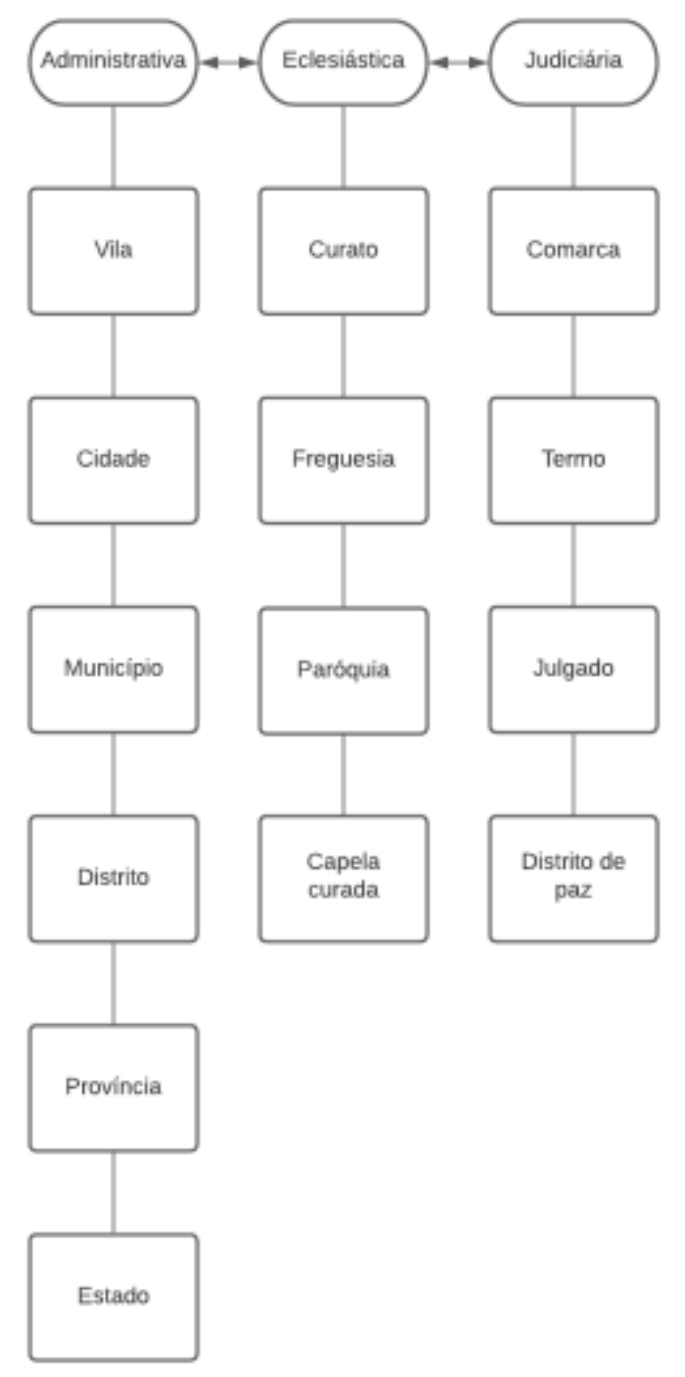

Fonte: Autores (2021).

A Figura 3 representa as diferentes categorias que compõem o ordenamento territorial, apesar da figura representar de forma linear e estrutura, é importante ressaltar que as categorias muitas vezes se confundiam e sobrepunham. O glossário a seguir busca representar os significados das categorias de uma maneira sintetizada para auxiliar a leitura do capítulo. 
Tabela 2:Glossário com significado das categorias que compõem o ordenamento territorial.

\begin{tabular}{|c|c|}
\hline \multicolumn{2}{|r|}{ Glossário } \\
\hline Categoria & Significado \\
\hline \multicolumn{2}{|l|}{ Administrativa } \\
\hline Vila & $\begin{array}{l}\text { Nos dicionários vila normalmente aparece como aglomerado populacional menor que a } \\
\text { cidade. A vila estabelece a criação de uma câmara, o que faz da vila a sede do antigo } \\
\text { termo e dos municípios. }\end{array}$ \\
\hline Cidade & Área com uma concentração de habitantes. A cidade é a sede do município. \\
\hline Município & $\begin{array}{l}\text { Divisão administrativa com circunscrição territorial própria. Apresenta certa autonomia } \\
\text { administrativa. }\end{array}$ \\
\hline Distrito & $\begin{array}{l}\text { O distrito é a circunscrição primária do território estadual, para fins de administração } \\
\text { pública e da organização judiciária. }\end{array}$ \\
\hline Província & $\begin{array}{l}\text { Entidade com certo grau de autonomia dotada de governo e constituição própria. No } \\
\text { Brasil surgiu a partir das capitanias e na república se transformou nos estados. }\end{array}$ \\
\hline Estado & $\begin{array}{l}\text { Entidade com certo grau de autonomia dotada de governo e constituição própria. O } \\
\text { território da União se subdivide em estados, enquanto os estados são subdivididos em } \\
\text { municípios. }\end{array}$ \\
\hline \multicolumn{2}{|l|}{ Eclesiástica } \\
\hline Curato & $\begin{array}{l}\text { Zona ou área provida de um cura (padre) residente para cuidar das atividades religiosas } \\
\text { sob a dependência de uma paróquia, mas com certa autonomia. }\end{array}$ \\
\hline Freguesia & $\begin{array}{l}\text { Definição primária da estância eclesiástica. A freguesia pode ser entendida como o } \\
\text { território que está sob jurisdição do pároco. A freguesia abrangia outros povoados que } \\
\text { não possuíam sua paróquia e acumulava funções administrativas. }\end{array}$ \\
\hline Paróquia & $\begin{array}{l}\text { Paróquia é o local onde contém seu próprio pároco e é celebrado o ofício divino. Pode- } \\
\text { se entender a paróquia como sinônimo da freguesia. }\end{array}$ \\
\hline Capela curada & $\begin{array}{l}\text { Localidades onde as capelas recebiam um cura provido pelos bispos, esse cura era } \\
\text { encarregado da assistência espiritual dos habitantes dos arraiais mais distantes da sede } \\
\text { da paróquia. }\end{array}$ \\
\hline \multicolumn{2}{|l|}{ Judiciária } \\
\hline Comarca & $\begin{array}{l}\text { O nome comarca se remete aquilo que é demarcado, limitado. Portando é uma } \\
\text { circunscrição jurídica que abrange a área em que o juiz exerce sua jurisdição. Pode } \\
\text { abranger um ou mais municípios. }\end{array}$ \\
\hline Termo & $\begin{array}{l}\text { Base territorial abrangida pela jurisdição de uma vila ou cidade, que seriam, as sedes } \\
\text { do poder. Por isso "Termo da vila" ou "Termo da cidade", pois nessas localidades se } \\
\text { encontravam a centralidade do poder, não só judiciário mas também político e } \\
\text { administrativo. }\end{array}$ \\
\hline Julgado & $\begin{array}{l}\text { Localidades distantes da sede de jurisdição da justiça criavam dificuldades para } \\
\text { administração da justiça. Nessa perspectiva que foram criados os julgados, que eram } \\
\text { novas sedes com autonomia parcial. }\end{array}$ \\
\hline Distrito de paz & $\begin{array}{l}\text { Os distritos de paz eram aquelas localidades que recebiam um juiz de paz (responsável } \\
\text { por decidir verbalmente pequenas contendas entre moradores de um determinado } \\
\text { local), como o juiz de paz atuava nos distritos, o local se elevava então a distrito de } \\
\text { paz. }\end{array}$ \\
\hline
\end{tabular}

Fonte: Autores (2021).

O processo de formação territorial de Minas Gerais foi impulsionado pela corrida pelo ouro. O primeiro povoado mineiro data 1674, denominado Ibituruna, a partir de então inicia-se a evolução organizacional do arcabouço políticoadministrativo. O modelo organizacional, devido ao período Brasil colônia tem forte influência da metrópole portuguesa. Em Portugal o elo principal da organização da malha urbana era o Concelho, que apresentava mesmo significado que vila e cidade (Fonseca, 2011).

O período colonial até 1822 foi marcado pela forte relação entre poder administrativo, eclesiástico e judiciário no ordenamento do territorial. As capitanias, que mais tarde foram chamadas de províncias, e finalmente na República foram 
intituladas como Estados, eram dividas no período colonial em: comarcas, termos, vilas, cidades, freguesias e paróquias. Todos as divisões faziam parte do ordenamento do território, e a mistura entre diferentes poderes atuando no ordenamento do território contribuiu para gerar certa dificuldade na interpretação da organização do mesmo.

A evolução territorial do estado de Minas Gerais inicialmente se remete a categoria arraial, que caiu em desuso, mas no século XVIII e XIX era central no espaço pré-urbano. O Arraial pode ser considerado a unidade primária da formação urbana, onde a partir desse estágio surgiam povoações mais consistentes. Tal terminologia chama atenção pelo fato de Portugal, principal influência no modelo organizacional brasileiro não utilizar esta categoria com o mesmo significado que este ganhou no Brasil pré-urbano. Em Portugal a incipiente aglomeração urbana era denominada aldeia ou povoado.

Segundo Mata a palavra arraial adquire uma variedade de significados, como acampamento militar, povoação temporária, pequena aldeia, ajuntamento festivo de povo entre outros significados. Porém Mata destaca que o sentido primitivo da palavra corresponde a acampamento, e que a evolução da palavra inserindo o termo real (de realeza), ocorreu pelo costume comum do soberano acompanhar seus exércitos nas campanhas, culminando na categorial do arraial (Mata, 2002).

Os relatos seiscentistas trazem o arraial com uma conotação militar, aparecendo sempre como sinônimo de acampamento. Mata também analisou diferentes tentativas de definição de arraial, entre elas apareceram que os arraiais foram acampamentos de mineradores ou vilarejos primitivos que se foram formando ao longo do processo colonizador. A melhor definição de arrais para Mata foi a do viajante Saint-Hilaire, que ao percorrer as terras das províncias na primeira metade do século XIX trouxe o seguinte relato sobre os arraiais:

Uma praça, por vezes bastante ampla e em formato retangular, em torno da qual dispunham-se habitações, e uma igreja ou capela - as vezes uma venda - compunham o perfil básico do arraial mineiro em fins do período colonial. Muitos deles permaneciam praticamente vazios durante os dias de semana, e só eram «preenchidos》 em ocasiões de missa e de festa. (Mata, 2002, p.50).

A partir da definição de Arraial e considerando a área de estudo, o atual município de Visconde do Rio Branco tem suas origens na criação de seu arraial. A criação do arraial de São João Batista do Presídio data 1787 e reforça como poder eclesiástico que apresentava grande influência na formação do espaço pré-urbano.

Vinte anos antes da criação do arraial o sacerdote Manoel de Jesus Maria se encontrava na região para incentivar seu crescimento e com a missão de ensinar princípios religiosos a população. Como vigário de S. Manoel dos Sertões do Rio Pomba e Peixe dos Índios Croatos e Cropós, Manoel de Jesus e Maria continuou seu trabalho missionário e em 1787 autorizouse a criação da capela dedicada a São João Batista. A inauguração da capela também naquele ano marca a criação do arraial de São João Batista do Presídio, a data inclusive se faz presente na bandeira do atual município (Pinto, 2002).

O arraial definia a formação do povoado inicial, não apresentava nenhum aspecto como definidor do ordenamento do território, mas era o primeiro passo, o seu contínuo desenvolvimento poderia significar no futuro a garantia de "títulos" maiores até a consolidação de uma possível vila. O caminho de desenvolvimento do arraial apresentava como próximo passo atingir um título da estância eclesiástica: freguesia.

A freguesia era uma definição primária da estância eclesiástica, mas apresentava forte ligação com poder administrativo no período colonial. Mata (2002) explica que apesar das freguesias se apresentarem como base da organização eclesiástica, elas exerciam também uma função administrativa, isso ocorria porque a partir da instituição das freguesias a metrópole passa a ter maior controle sobre os arraiais que estavam surgindo. Além disso, Fonseca (2011) esclarece que as freguesias serviam como base para a realização dos recenseamentos e das cobranças de impostos por parte do poder administrativo. Por fim, Marx (1991) explana que enquanto as instâncias administrativas estavam distantes dos arraiais que surgiam afastados dos grandes núcleos de interesse da metrópole, a igreja no início do desenvolvimento dessas localidades já 
impunha suas questões hierárquicas.

A categoria freguesia tem como sinônimo a paróquia. Martins e Soares em pesquisa nos dicionários sobre as duas palavras concluíram que ambas apresentam semelhanças que os colocam como sinônimos. Em suas pesquisas encontraram que Parochia em grego quer dizer vizinhança, e também é na paróquia o local onde através do pároco e de seus vigários que é celebrado o ofício divino. Pode-se estender também o significado como o território que está sob a jurisdição do pároco (Martins \& Soares, 2016).

O reconhecimento da construção de uma capela pela igreja representava um marco, pois a partir de então aquele povoado se tornava mais estável e consolidado. Basicamente a titulação de freguesia, significava que o povoado pelos seus aspectos populacionais e de desenvolvimento já se encontravam em um estágio para ter o seu próprio pároco.

A organização eclesiástica na província mineira se assemelhava a organização europeia. A freguesia era a representação do templo - igreja -, da povoação sede, das áreas rurais e também abrangiam outras povoações incipientes (arraiais) que ainda não eram freguesias.

A elevação do arraial a freguesia oficializava a unidade territorial perante o Estado. Porém o novo status garantia para a população outras benfeitorias. A população passa a adquirir o direito a assistência religiosa e aos processos que permeavam pela responsabilidade da igreja. Não era necessário mais locomover uma grande distância para o batismo, o mesmo válido para o casamento ou para o sacramento na morte. A agora paróquia também tinha a responsabilidade perante o estado de registrar os acontecimentos da comunidade como os registros de nascimento e de óbito. São esses os fatores que explicam o anseio da comunidade de dar um passo maior do que apenas construir uma capela para suas atividades religiosas, almejava-se também a sua oficialização e reconhecimento como paróquia. Tal status além de garantir o simbolismo de sagrar aquele espaço e do reconhecimento perante o Estado, garantia também uma série de facilidades a população (Marx, 1991).

O arraial de São João Batista do Presídio reconhecido como tal em 1787, permaneceu com esse status até 1810, quando então foi elevado a nova condição de freguesia, ou seja, a construção de sua capela que garantiu o reconhecimento do arraial em 1787 fora elevada a paróquia, consolidando a freguesia.

O documento que consolida a freguesia trata-se da Resolução de 24 de julho de 1810, quando este coloca que "erige em freguesia a Capela Curada do Presídio de São João Batista, do Bispado de Mariana”. No documento consta que o requerimento a elevação da Capela Curada a freguesia foi recusado pelo Bispo de Mariana, que naquele período era Cipriano de São José, porém ele foi voto vencido, tendo o Procurador da Coroa e da Fazenda acatado positivamente o requerimento.

A resolução de 24 de julho de 1810 remete em seu texto a elevação de Capela Curada a freguesia. Tendo em vista o que já foi elucidado sobre a categoria freguesia, a compreensão do seu significado é clara. Porém a categoria Capela Curada que está presente na resolução carece de uma explicação do seu significado.

A Capela Curada remete as classificações eclesiásticas auferidas pelo poder da Igreja. Neste período ocorria uma divisão em curatos e freguesias coladas. A diferença entre elas se dá basicamente pelo fato de os curatos receberem um vigário encomendado pelo bispo, enquanto na freguesia o vigário era indicado pelo rei. Além dessas existiam também a Capela Curada definida por Martins e Soares (2016) como aquelas em que recebiam uma cura provido pelos bispos, e esse cura era encarregado da assistência espiritual aos habitantes dos arraiais e fazendas mais distantes da sede da paróquia.

A partir da definição da Capela Curada é possível explicar tal título a então capela de São João Batista do Presídio antes desta ser elevada a freguesia em 1810. Como definiu Martins e Soares, as Capelas Curadas eram aquelas que recebiam assistência de um padre, onde esse saia da sede da paróquia para atender as pessoas assistidas pela Capela Curada. Nesta perspectiva, sabe-se que o vigário Manoel de Jesus e Maria da Freguesia de Mártir São Manoel do Rio da Pomba e Peixe dos Índios Croatos e Cropós prestava assistência a capela de São João Batista do Presídio, tendo inclusive auxiliado em sua fundação como mencionado neste capítulo. A freguesia do vigário Manoel era a única com este título na região próxima ao 
arraial São João Batista do Presídio no período em questão. Logo, sua participação na capela a classificou como Capela Curada.

O primeiro momento que se remete até 1828, se perpassa majoritariamente pelo Brasil colônia. A organização administrativa neste período permeava ao entorno de duas estâncias: vilas e cidades.

A vila aparece nos dicionários do século XVIII como povoação de menor graduação que a cidade, porém maior que a aldeia. Para ser considerado vila também era necessário a presença de juiz, câmara e pelourinho. Logo, era na vila o centro do poder civil, judiciário e religioso. Assim, quando se elevava determinado povoado a condição de vila, ocorria a criação da câmara e a formação dos oficiais camarários, estes oficiais correspondiam aos vereadores e um juiz eleito ou indicado pela coroa (Martins \& Soares, 2016).

A cidade no século XVIII apresentava-se no dicionário como povoação superior a vila. O título de cidade significava o enobrecimento daquele local e de sua população. O título era requerido quando aquela localidade conseguia feitos importantes e também quando era local de residência de pessoas respeitáveis. Porém o título de cidade era apenas honroso, pois a elevação de uma vila a condição de cidade não garantia outras obrigações ou benefícios (Fonseca, 2011).

O período em questão quando analisado a área de estudo evidencia-se que não existia pela região a presença de vilas ou cidades. Como se trata do grau mais avançado que uma localidade poderia receber, apenas as povoações que eclodiram primeiro a receberam. No período colonial, apenas dezesseis povoados da província se elevaram a condição de vila, e esses povoados se localizavam na região da mineração onde estava centrada a ocupação impulsionada pelo fascínio ao ouro.

A região da Mata ou os sertões do leste pelo fato de permanecerem por um período maior como áreas inexploradas não detinham nenhuma povoação com o grau de cidade ou vila. Mesmo que em algumas áreas da Mata suas ocupações sejam tão antigas quanto as da região das minas, a estrutura dos povoados não atingira a expressão que aqueles localizados na região central mineradora. Para os governantes os povoados da Mata não apresentavam importância econômica, nobreza dos habitantes, beleza das igrejas ou ruas regulares para conferirem títulos mais elevados aos seus arraiais. A situação é corroborada quando observa-se o marco temporal das elevações das vilas na região da Mata, onde a primeira vila na região somente foi erguida 1831, através da Vila de São Manoel do Pomba, sendo a segunda à Vila de São João Batista do Presídio em 1839 (Carneiro \& Matos, 2010).

A organização judiciária neste período se dividia em comarcas, julgados e termos. A Comarca engloba diversos municípios que estão sujeitos ao poder Judiciário de uma sede. Anteriormente a 1828, tendo em vista que a categoria município ainda não era utilizada no Brasil, a Comarca englobava diversas vilas, cidades e arraiais. A Comarca no Brasil colônia consistia em uma jurisdição que era exercida por um ouvidor, e refere-se a divisão territorial do Estado quanto a área de influência da justiça (Martins \& Soares, 2016).

Os julgados foram criados com a finalidade de administrar a justiça em maior extensão territorial da província. Como no século XVIII existiam poucas vilas, essas vilas apresentavam uma grande extensão territorial e vários arraiais ficavam distantes da sede de jurisdição. Visando solucionar essa questão os julgados foram criados em alguns arraiais com autonomia judiciária, mas submetidos administrativamente a sede da vila (Fonseca, 2011).

Os termos basicamente se referem ao espaço de abrangência da jurisdição de seus juízes. A sede do termo (câmara) localiza-se na povoação principal, ou seja, a vila. Por isso encontra-se em leis informações referentes a "termo da vila", já que esta demarca a extensão territorial que está subjugada pelo poder das decisões na câmara. Pode-se dizer que o sucessor do termo será o município, a diferença entre o termo e o município é que o primeiro refere-se a uma divisão do território para suprir questões judiciárias, já o município surgirá voltado para questões administrativas (Martins \& Soares, 2016).

A Comarca no Brasil colônia consistia em uma jurisdição que era exercida por um ouvidor, enquanto no Brasil império a jurisdição passou a ser exercida por um Juiz de Direito, indicado pelo Imperador. No Brasil república, foi mantido a 
Comarca como termo administrativo da justiça. Logo, apesar de mudanças referentes a jurisdição interna das Comarcas, desde a sua criação até os dias atuais esta refere-se a divisão territorial do Estado quanto a área de influência da justiça (Martins \& Soares, 2016).

Através da Lei Geral de $1^{\circ}$ de outubro de 1828 foi introduzido e reforçado o conceito de Município. Definiu-se que as cidades ou vilas seriam as sedes dos municípios. Também em seu artigo 24 estabeleceu que as Câmaras municipais são responsáveis por funções administrativas, e não mais judiciárias como ocorriam com o Termo, demonstrando aqui um avanço na separação do território quanto a organização administrativa e judiciária, o que não ocorria no primeiro momento. Por essa questão considera-se 1828 como ponto central da mudança do primeiro para o segundo momento do processo da divisão política-administrativa e territorial.

A organização administrativa a partir de 1828 era abalizada na vila e nas cidades. As que já existiam neste período e as que surgiriam estavam sujeitas a esfera da municipalidade. O poder político e administrativo em todo território do município seria exercido através da Câmara Municipal construída na vila ou na cidade, logo, tanto a vila como a cidade se tratavam da sede da administração do município. Se no período colonial a diferença entre a vila e a cidade se dava apenas por um título honroso, neste segundo momento a diferença entre elas se estende um pouco além da questão honorífica. Segundo a Lei de $1^{\circ}$ de outubro de 1828 em seu artigo primeiro, enquanto a cidade possuía em sua câmara nove membros, a vila contava com sete.

A garantia de se tornar sede de um município, ter o seu território bem definido como uma unidade autônoma dentro da província e a possibilidade de zelar pelos próprios anseios, despertava um grande interesse do povoado de se elevar até a situação de vila ou cidade. Seguindo as etapas do desenvolvimento urbano, quem pleiteava o status de vila eram as freguesias, estas aspiravam algo maior que a oficialização inicial concedida pelo poder eclesiástico e administrativo que possuía uma freguesia. Outro ponto que garantia o anseio da freguesia em se elevar a vila, é que se a administração do município estivesse sediada em outra sede, consequentemente as questões primordiais discutidas na câmara seriam em referência a sede, as demais aglomerações teriam grandes chances de ter suas demandas negligenciadas (Marx, 1991).

A freguesia para se elevar a vila deveria dar prosseguimento ao mesmo crescimento que a garantiu seu status atual. Ou seja, aumentar sua população, número de fogos e de serviços até um ponto que esse notado crescimento poderia se concretizar em elevação da sua categoria institucional. Porém é válido ressaltar que os relatos de viajantes pelas freguesias e vilas de Minas Gerais relatam que os crescimentos ocorriam de forma lenta ao longo do tempo, tanto que até mesmo após a elevação a vila a aparência e tipo de vida se mantinham. Outro fator é que muitos locais elevados a vila não justificavam pelo seu desenvolvimento, mas sim pela influência política. De qualquer forma, notado tal crescimento mesmo que lento em alguma freguesia, a ereção a vila era pleiteada e caso se concretizasse era necessário a tomada de diversas providências para organizar o território. Entre elas a delimitação do território do novo município em acordo com os limites com os municípios mais antigos e a definição das freguesias e demais arraiais que se enquadrariam naquele município além de sua sede (Marx, 1991).

A partir do período monárquico, a elevação a vila na província mineira se iniciou na década de 1830. É importante ressaltar que desde 1814 não ocorria a criação de vilas, o que acabou gerando uma demanda por novas divisões administrativas. Essa demanda se pautava em interesses políticos e conflitos por limites territoriais. Outro contexto importante que surgiu nesse período foi a mudança da principal atividade econômica, que passou da mineração para agropecuária. Apesar da mudança a rede urbana mineira ainda se concentrava ao entorno da antiga região mineradora, o que também foi um fator de pressão para criação de novas vilas. A partir desse novo cenário, somente na década de 1830 vinte e três vilas foram criadas. O número é tão expressivo que em todo século XIX foram erigidas noventa e cinco vilas (Chaves, 2013).

Além da conjuntura exposta anteriormente, as mudanças no processo de arrecadação que ocorreram através da Lei de 4 de outubro de 1831 e 15 de novembro de 1831 causaram mudanças incisivas na criação de vilas na província. Após a implementação das leis, o surto de elevação de vários arraiais para a condição de vila se espalhou por Minas Gerais com um 
motivo de instalar repartições públicas para arrecadação de impostos. Dentro dessa lógica, insere-se a elevação a vila de Rio Pomba em 1831. A partir desta vila que São João Batista do Presídio se emancipou ainda no final da mesma década (Carrara \& Machado, 2020).

A então freguesia de São João Batista do Presídio elevou-se a vila em 1839. De acordo com a lei número 134 de 16 de março daquele ano a então Vila de São João Batista do Presídio consistia na sede administrativa do município que detinha como território a freguesia de mesmo nome e também as de Santa Rita do Turvo e Arrepiados, que atualmente apresentam o topônimo de Viçosa e Araponga. Após a publicação da lei, em 21 de setembro do mesmo ano instaurou o funcionamento da câmara municipal dando início a função administrativa as terras do município.

No presente texto levantou-se a questão da elevação de determinadas vilas por motivos de poderes políticos que não justificavam pelo seu grau de desenvolvimento. Porém quando considera o grau de desenvolvimento a partir da análise do número de fogos (habitação), constata-se que para os povoados presentes na região da mata em 1830, São João Batista do Presídio apresentava o quarto com o maior contingente com oitenta e quatro fogos. Para um total de trinta e cinco povoações com dados do número de fogos, São João Batista do Presídio encontrava-se atrás apenas de Piranga, Ponte Nova e Itaverava, povoados mais distantes. Logo, pelo número de fogos, São João Batista do Presídio apresentava um desenvolvimento significativo se comparado com outros povoados vizinhos, corroborando com o fato que a elevação de São João Batista do Presídio a vila em 1839 a princípio se pautava em seu desenvolvimento.

A freguesia de São João Batista do Presídio, após ser elevada a vila em 1839, passou por processos de mudança do seu território em diferentes períodos, todos eles envolvendo São Januário de Ubá, atual município de Ubá. Em 1853 ocorreu a primeira alteração, com a transferência da sede da vila para o arraial de São Januário de Ubá. Dessa maneira a então vila do Presídio foi suprimida e passou à condição de distrito. Tal fato se consolida pela lei provincial número 654, de 17 de junho de 1853, cujo artigo primeiro estabeleceu que ficavam "transferidas a sede da vila do Presídio para o arraial de São Januário de Ubá com a denominação de vila de São Januário de Ubá.” (Minas Gerais, 1853).

Pouco depois, a lei provincial número 1573, de 22 de julho de 1868, em seu artigo único determinou a transferência da sede do município de Ubá "para a freguesia do Presídio, tomando a denominação de cidade de São João Batista do Presídio". Três anos depois, a lei provincial nº 1755 , de 22 de setembro de 1871 restaurou a sede do município em Ubá. A última alteração ocorreu em cumprimento da lei provincial de número 2785 , de 22 de setembro de 1881 que em seu artigo segundo definiu a criação dos municípios de São João Batista do Presídio, "composto das freguesias deste nome, elevado à categoria de vila, de Bagres e de São José do Barroso, desmembradas todas do termo de São Januário de Ubá, ficando este novo município pertencendo à comarca de Ubá". Vale ressaltar que a freguesia de Bagres e de São José do Barroso que também foram desmembradas de Ubá e passaram a pertencer a São João Batista do Presídio, são atualmente os municípios de Guiricema e Paula Cândido respectivamente.

As alterações citadas não constituem evento isolado e inusitado na história política-administrativa do território mineiro. Aliás, casos parecidos ocorreram com certa recorrência. Segundo Costa (1997), as condições com que foram criados diversos municípios na província mineira fizeram com que vários deles apresentassem uma existência precária, e consequentemente sofressem com atos de supressão, para somente em anos posteriores serem novamente elevados a município. As supressões ocorreram - como no caso de Presídio - por meio da transferência de sede do município para outra povoação, já outros casos se definiam apenas com a extinção do município. Os municípios que passaram por esse processo em Minas Gerais nos dois primeiros séculos, com a capitania e depois com a província, somam trinta casos, sendo dois deles referentes a Ubá e Visconde do Rio Branco.

$\mathrm{Na}$ análise dos casos de supressões, foi possível identificar a ausência de uma norma que pré-estabelecesse critérios sólidos que definissem quando suprimir um município. E conforme esclareceu Costa (1997), a supressão em boa parte dos 
casos significava a transferência da sede para uma outra povoação. Dessa forma, um padrão identificável é que a transferência de sede para outra povoação ocorria quando a então sede perdia o posto de principal ou maior povoado no que tange o desenvolvimento urbano. Logo, o crescimento e o desenvolvimento de um outro povoado que supere o da sede, poderia resultar em uma transferência de sede do município.

No caso de Visconde do Rio Branco e Ubá, as transferências ocorreram baseadas nos motivos citados no parágrafo anterior, complementada por uma disputa política entre os povoados para qual de fato deveria ser a sede do município.

Na década de trinta do século XIX, o povoado de São João Batista do Presídio apresentava maior grau de desenvolvimento urbano frente ao povoado de São Januário de Ubá, ou seja, apresentava maior grau de complexidade dos serviços prestados em sua sede. O número de fogos no povoado do Presídio neste período era superior a quatro vezes o número de fogos em São Januário, enquanto o povoado de São Januário apresentava 19 fogos, o do Presídio continha 84 fogos, logo essa diferença justifica a criação do município de Presídio em 1839, com a sede em seu povoado (Minas Gerais, 1897).

Nas décadas seguintes o crescimento do povoado de São Januário resultou nas transições de sedes mediante a decisões tomadas pela assembleia legislativa da província. O censo do IBGE de 1872, um ano após a transferência de sede para Ubá, demonstra o crescimento de Ubá em um ritmo mais acelerado que do Presídio. Através do censo, analisando o número de fogos, a paróquia de São Januário de Ubá apresentava 1244 fogos, e uma população total de 11267 pessoas. Já a paróquia de São João Batista do Presídio continha 987 fogos, e uma população de 6078 pessoas.

No processo de transferência de sede entre Ubá e Visconde do Rio Branco no século XIX, o interesse em se manter ou se tornar a sede se manifestava em disputas através dos principais nomes políticos dos povoados. Algo justificável, na medida que se a administração do município se encontra em outra sede, maiores são as chances de suas demandas serem negligenciadas. Nessa perspectiva, Carlos Peixoto de Melo prefeito de Ubá em 1868, renunciou a seu cargo quanto a possibilidade de transferência da sede do município para Presídio, o que de fato ocorreu naquele ano. Porém o mesmo teve papel fundamental na articulação para devolver o status de sede do município para Ubá em 1871. A disputa neste período se deu por parte dos conservadores de Carlos Peixoto de Melo contra os liberais de Presídio (Carneiro Filho, 2009).

No período imperial a Vila de São João Batista do Presídio após o imbróglio de supressões e elevações que perdurou até 1881 foi elevada ao maior nível hierárquico administrativo. Através da lei provincial número 2995 de 19 de outubro de 1882, o artigo único descreve: "Fica elevada à categoria de cidade, com o título de cidade Visconde do Rio Branco, a vila do Presídio". A elevação da vila a cidade ocorreu um ano após Presídio retomar a condição de vila, tendo em vista que até 1881 sua vila estava suprimida a condição de distrito de Ubá. Outro ponto é que o grau de cidade acompanhou um novo topônimo. O novo nome em homenagem ao estadista José Maria da Silva Paranhos, o Visconde do Rio Branco foi uma iniciativa do então deputado José Pedro Xavier da Veiga.

A partir da república iniciou uma série de medidas que buscavam sanar os diferentes imbróglios que existiam ao entorno da organização do território. Se anteriormente a criação de vilas e cidades não respeitavam um padrão estabelecido, a partir da república aos poucos são criadas leis que buscavam definir critérios mais sólidos. A separação entre a organização administrativa e judiciária foi ficando cada vez mais consolidada, e finalmente a desvinculação entre Igreja e Estado colocou fim nos conflitos existentes entre os limites de freguesias.

A primeira mudança de grande impacto na república que altera de maneira significante a organização territorial se deu através da constituição de Minas Gerais de 1891. O seu artigo 74 definiu que a base da divisão dos municípios são os distritos, e foi a partir de então que se abandonou a divisão eclesiástica em paróquia e freguesia que persistiu durante o período colonial e imperial (Brasil, 1891).

Ao tratar da área de estudo, o mapa de Rio Branco produzido pela Comissão Mineira do Centenário em 1927 retrata como o território se ordenava, é possível notar o fim da divisão eclesiástica e os municípios divididos em distrito. Em 1927 o 
município de Rio Branco era composto pelos distritos de Guiricema, São Geraldo e Barroso (atualmente Paula Cândido).

Figura 4: Mapa de Rio Branco produzido pela Comissão Mineira do Centenário em 1927.

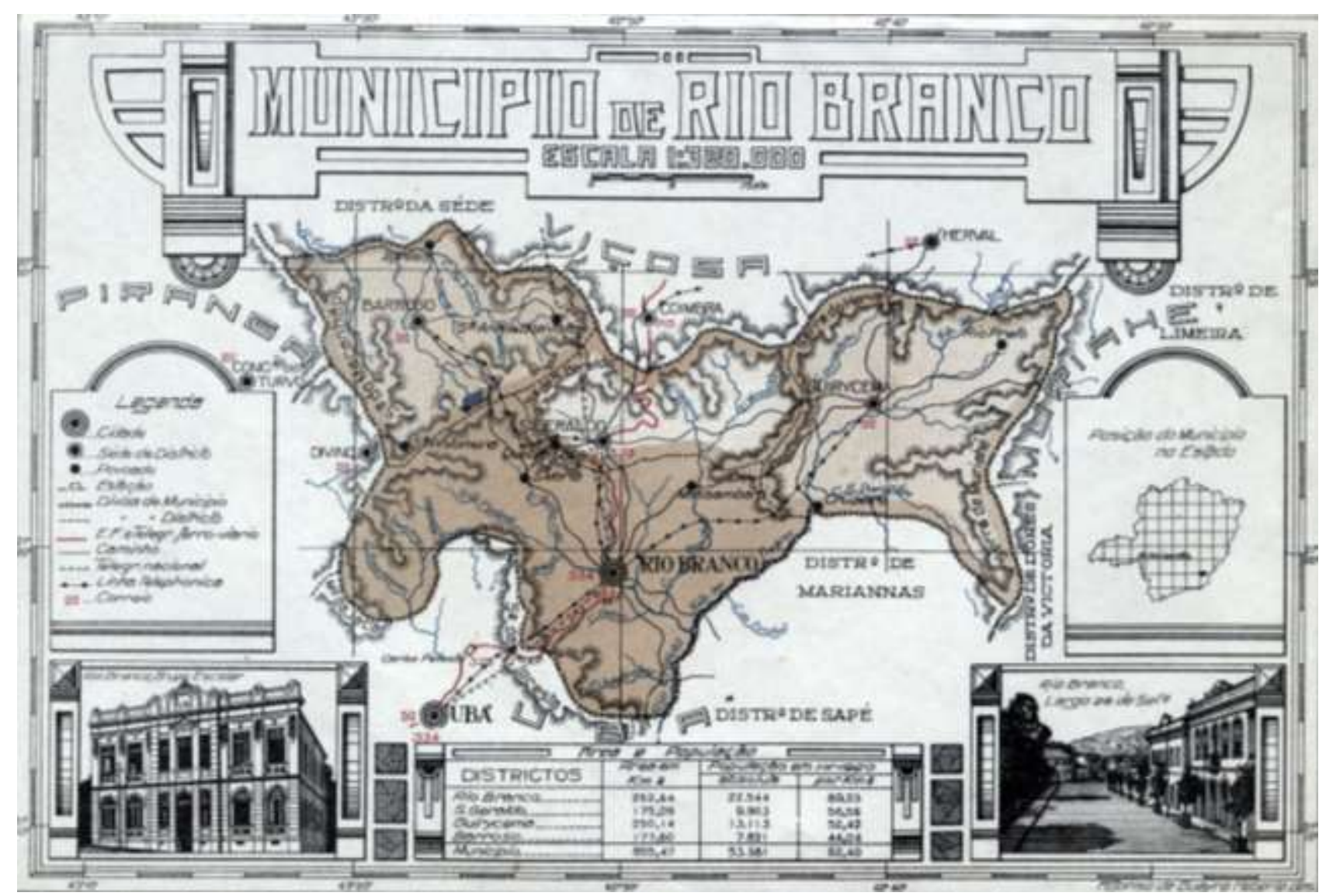

Fonte: Minas Gerais (1927).

Os distritos, diferentemente dos distritos de paz do período monárquico são territórios de organização administrativa inseridos no município. Logo sua circunscrição territorial demarcava até sobre onde se estendia os interesses administrativos próprios daquele distrito. Porém é válido ressaltar que o distrito administrativo, agora na república, apresenta vínculo com os distritos de paz que existiam no período monárquico e se referiam a organização judiciária. Segundo Martins e Soares (2016), todos os distritos de paz existentes no Brasil Império formaram os primeiros distritos administrativos na república em Minas Gerais.

No que se refere ao uso da Cartografia Histórica para retratar o ordenamento territorial a partir de um mapa histórico, utiliza-se o mapa de João José da Silva Theodoro de 1847. Assim como os demais mapas históricos, foram elaborados com técnicas existentes no seu tempo, portanto não apresentam a mesma exatidão que os mapas produzidos atualmente. Logo, é importante deixar claro que a utilização do mapa histórico neste trabalho não tem como objetivo atingir os níveis de precisão definidos pela PEC (Padrão de Exatidão Cartográfica), que é o indicador estatístico atual para considerar um produto cartográfico como um documento de referência. Mas através da metodologia descrita, torna possível transformar o mapa histórico em informação localizável e de fácil interpretação para o leitor.

O relatório elaborado por João José da Silva Theodoro sobre a construção do mapa reforça a questão da impossibilidade de demarcar os limites com acurácia. Nele Theodoro esclarece que ao tentar demarcar os limites da província de Minas Gerais com a do Rio de Janeiro, constatou que por não se adotar limites naturais os próprios moradores não sabem a qual província pertencem. Referente as divisas eclesiásticas, Theodoro constatou os mesmos problemas, e ainda manifestou no 
relatório a questão da sobreposição das demarcações civis e eclesiásticas, já que segundo ele algumas freguesias estendiam seu território além do limite da província de Minas Gerais (Theodoro, 1847).

No relatório Theodoro esclarece sobre as demarcações dos municípios de São João Nepomuceno, Pomba e Presídio que qualquer tentativa de demarcação minuciosa das divisas seria inútil, tendo em vista que "o curso tortuoso que estabelecem boa parte das divisas entre os municípios não estão definidos por lugares naturais, ou estáveis" (Theodoro, 1847).

Apesar da dificuldade de estabelecer demarcações precisas para o período, destaca-se como o mapa do Theodoro auxilia a compreender como o território estava organizado.

No processo de trabalhar com o mapa do Theodoro, foram levantados 41 pontos, entre vilas, freguesias, curatos e capelas. Todos as 41 localidades foram identificadas na base de dados formada pelas cartas topográficas georreferenciadas. Esta etapa permitiu posteriormente associar pontos de mesma localização geográfica, e assim georreferenciar o mapa do Theodoro utilizando as 41 localidades como pontos de controle através do método master/slave descrito na metodologia.

O processo de identificação dos pontos comuns exigiu um trabalho investigativo, paisagens naturais como rios e serras auxiliaram a identificar determinados pontos. Outra questão é a alteração dos nomes, o mapa de João José da Silva Theodoro foi realizado em 1847, enquanto as cartas topográficas foram realizadas na década de 70 e 80, o intervalo superior a cem anos é suficiente para que os nomes próprios dos lugares sejam alterados. Nessa perspectiva, esta parte do trabalho entrou no campo da toponímia.

A realização do estudo da histórica-política administra e territorial requer uma atenção a denominação dos lugares. Pode-se imaginar que as denominações dos municípios e dos lugares como conhecemos atualmente estão sujeitas a alterações, logo, quando retomamos a organização política-administrativa e territorial no tempo pretérito, torna necessário conhecer as possíveis mudanças de nomes que ocorreram ao longo do tempo.

O campo que estuda os nomes próprios dos lugares, bem como sua origem e evolução é a toponímia. Desde que o homem descobre um lugar novo e ele passa a ter alguma significação, consequentemente deve-se pensar em um nome. O nome que aquele lugar recebe está atrelado a alguma particularidade do local, revelando um pouco de sua história, portanto a toponímia está atrelada a história e a cultura dos lugares (Seeman, 2005).

Os nomes próprios dos lugares no Brasil estão atrelados principalmente a característica hidrográfica ou a vegetação, também relacionado ao nome de uma pessoa que representa alguma relevância para aquele lugar, como também uma análise dos topônimos podem evidenciar uma forte relação entre os nomes dos lugares com a religião. Constantes são os nomes dos lugares brasileiros que representam nome do rio, alguma espécie de planta característica daquele local e nome de santos católicos.

A própria vila de São João Batista do Presídio sofreu diversas alterações no seu nome próprio ao longo de sua história. Em um primeiro momento a localidade recebeu o nome de Zona do Rio Xopotó dos Coroados, remetendo aos índios Croatos ou Coroados que ocupavam a região. Quando aldeia, recebeu nome de Aldeia do Xopotó, e no início do século XIX recebeu nome de São João Batista do Presídio. A localidade era cercada por mata fechada, e por isso recebia presos políticos e comuns para cumprir pena, o presídio era aberto mas fugir daquela localidade era difícil, já outra versão diz que naquela localidade existia uma cadeia, logo, alguma destas versões que justificam o nome do Presídio (Pinto, 2002). Por fim, a localidade recebeu o nome de Rio Branco e Visconde do Rio Branco, uma homenagem ao estadista José Maria da Silva Paranhos, o Visconde do Rio Branco.

O estudo da toponímia fornece também um aparato importante para a cartografia histórica. Uma análise da área a partir das cartas topográficas recentes, comparadas com uma análise do mapa de João José da Silva Theodoro de meados do século XIX apresentará nomes distintos para locais de mesma coordenada geográfica.

Diante disso, através da investigação utilizando as leis provinciais e estaduais que se encontram em meio digital no 
arquivo público mineiro e na Assembleia Legislativa de Minas Gerais e do livro Enciclopédia dos Municípios de Minas Gerais realizou-se um levantamento das mudanças de toponímia a partir das vilas, freguesias, curatos e capelas. A identificação dos topônimos é importante para entender como os lugares de mesma localização geográfica apresentam nomes distintos ao decorrer do tempo.

Após a identificação foi realizada uma tabela com os 41 lugares selecionados no mapa do Theodoro. A tabela descreve as alterações nos nomes, apresentando o nome antigo e o atual, e também demonstra em qual categoria do ordenamento territorial aquele lugar se enquadrava em 1847, e qual a sua categoria atual. Os lugares com asterisco representam somente os pertencentes ao antigo município do Presídio.

Tabela 3: Toponímia e categoria dos pontos demarcados no mapa do Theodoro.

\begin{tabular}{|c|c|c|c|}
\hline \multicolumn{2}{|l|}{1847} & \multicolumn{2}{|l|}{ Atual } \\
\hline Nome & Situação & Nome & Situação \\
\hline Presídio de São João Batista* & Município & Visconde do Rio Branco & Município \\
\hline Pomba & Município & Rio Pomba & Município \\
\hline São João Nepomuceno & Município & São João Nepomuceno & Município \\
\hline São Paulo* & Freguesia & Muriaé & Município \\
\hline São Miguel das Almas* & Freguesia & Araponga & Município \\
\hline Santo Antônio de Pádua & Freguesia & Santo Antônio de Pádua & Município \\
\hline Mercês do Pomba & Freguesia & Mercês & Município \\
\hline Santa Rita do Turvo* & Freguesia & Viçosa & Município \\
\hline São Januário de Ubá* & Freguesia & Ubá & Município \\
\hline São Sebastião do Feijão Crú* & Curato & Leopoldina & Município \\
\hline Madre Deus d'Angu & Curato & Angustura & Distrito \\
\hline Santo Antônio da Brota & Capela & Miracema & Município \\
\hline Barra do Bacalhau & Capela & Guaraciaba & Município \\
\hline Bom Jesus do Rio Pardo & Capela & Argirita & Município \\
\hline Santo Antônio & Capela & Porciúncula & Município \\
\hline São Caetano do Xopotó & Capela & Cipotânea & Município \\
\hline Livramento & Capela & Oliveira Fortes & Município \\
\hline São Francisco das Esteiras* & Capela & São Francisco do Glória & Município \\
\hline São Sebastião do Anta* & Capela & Pedra do Anta & Município \\
\hline Bom Jesus do Tabuleiro & Capela & Tabuleiro & Município \\
\hline Conceição do Turvo* & Capela & Senador Firmino & Município \\
\hline Dores do Turvo* & Capela & Dores do Turvo & Município \\
\hline Brás Pires* & Capela & Brás Pires & Município \\
\hline São Sebastião dos Aflitos* & Capela & Ervália & Município \\
\hline São Francisco de Assis* & Capela & Palma & Município \\
\hline Espírito Santo do Piau & Capela & Piau & Município \\
\hline Conceição do Rio Novo & Capela & Rio Novo & Município \\
\hline Santa Trindade do Descoberto & Capela & Descoberto & Município \\
\hline São José do Paraopeba* & Capela & Tocantins & Município \\
\hline José do Bagre* & Capela & Guiricema & Município \\
\hline São José do Barroso* & Capela & Paula Cândido & Município \\
\hline Santa Rita da Meia Pataca* & Capela & Cataguases & Município \\
\hline Patrocínio & Capela & Patrocínio do Muriaé & Município \\
\hline Santo Antônio do Porto* & Capela & Astolfo Dutra & Município \\
\hline Glória & Capela & Itamuri & Distrito \\
\hline Conceição & Capela & Conceição da Boa Vista & Distrito \\
\hline Natividade & Capela & Piacatuba & Distrito \\
\hline Dores do Rabicho & Capela & Taruaçu & Distrito \\
\hline Santana do Sapé* & Capela & Guidoval & Município \\
\hline
\end{tabular}

Fonte: Autores (2021).

Através da análise dos 41 pontos demarcados no mapa de Theodoro foi possível constatar que 36 pontos atualmente evoluíram da categoria que pertenciam em 1847 para município. Reafirmando o surto de criação de novos municípios como já comentado no presente trabalho. 
Após a utilização dos pontos de controle para georreferenciar o mapa, foi possível construir um mapa temático (figura 5) que represente o ordenamento do território e 1847. No processo de georreferenciamento, ao associar as coordenadas precisas dos pontos das cartas topográficas com o mapa histórico, constatou o deslocamento de alguns pontos, algo já esperado pelo fato de se tratar de um mapa produzido no século XIX. O deslocamento dos pontos variou entre $1 \mathrm{a} 2 \mathrm{~cm}$ no mapa, o que representa 5 a $10 \mathrm{~km}$ de deslocamento no terreno em alguns pontos, porém para a escala trabalhada e para os fins de compreensão do ordenamento do território o deslocamento não interfere negativamente.

Figura 5: Vetorização do Mapa Topográfico dos Municípios do Presídio, Pomba e São João Nepomuceno em 1847.

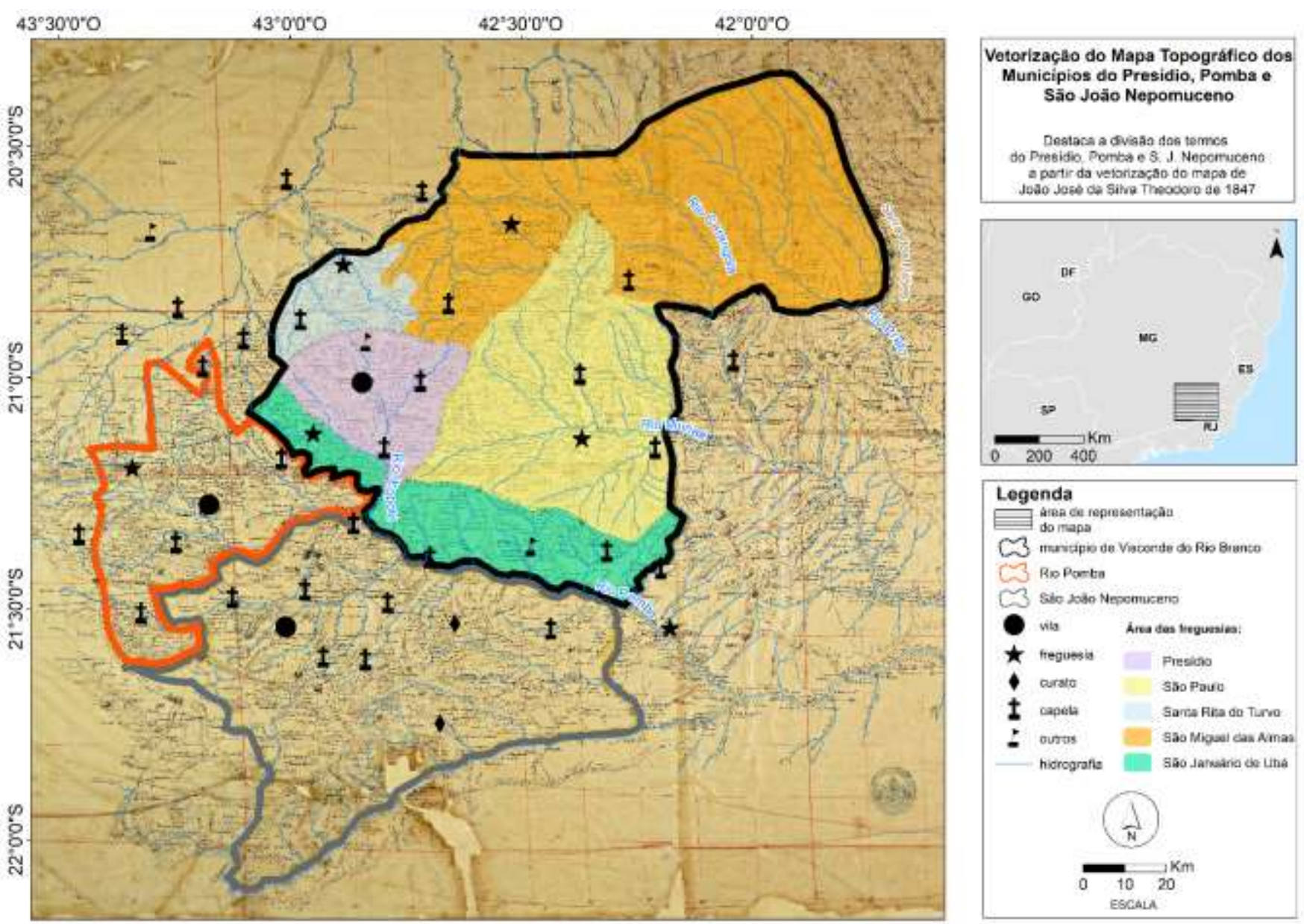

Fonte: Autores (2021).

O mapa (Figura 5) utiliza o mapa de João José da Silva Theodoro georreferenciado com algumas informações essenciais destacadas através da vetorização. O mapa representa três municípios: Presídio, Pomba e São João Nepomuceno, além dos três municípios destaca-se diversas categorias: vilas, freguesias, curatos e capelas.

A partir do mapa é possível constatar o ordenamento do município do Presídio. A vila do Presídio é demarcada com um círculo preto, é na vila que está a câmara, e a extensão territorial subjugada pelo poder das decisões tomadas na câmara se estende aos limites demarcados pela linha de cor preta.

Além da divisão administrativa, o território também se subdividia na divisão eclesiástica. As freguesias tinham seus territórios reconhecidos pelo Estado, e a sede era responsável por registrar os acontecimentos como nascimentos e óbitos até onde se estendia suas divisas. O município do Presídio quando criado, continha em seu território três freguesias: Arrepiados (Araponga), Santa Rita do Turvo (Viçosa) e a do próprio Presídio (Visconde do Rio Branco), já em 1847, identifica-se duas 
novas freguesias: São Januário de Ubá (Ubá) e São Paulo (Muriaé), compondo assim a divisão eclesiástica da área de estudo.

No que se refere a divisão eclesiástica, João José da Silva Theodoro esclarece que as freguesias não apresentam divisas claras, e em vários pontos não são consideradas as paisagens naturais para a delimitação do território. O fato da sede da freguesia não se localizar em uma área central do seu território também chama a atenção de Theodoro. Em seu relatório, sobre a demarcação da freguesia de São Januário de Ubá, Theodoro clarifica que o território da freguesia é extremamente estreito a noroeste, e muito extenso a sudeste, ficando uma grande parcela do território isolada da sede. Além desse fator, sobre o território da freguesia de São Januário de Ubá, chama atenção de Theodoro o fato da divisa ser cortada pelas freguesias do Presídio e de Pomba, que se unem no rio Xopotó (também chamado naquele período de rio do Presídio), portanto o pároco para passar para maior extensão de terras de sua jurisdição, obrigatoriamente deve passar pelas divisas das freguesias de Presídio e Pomba, este fato é facilmente observado na Figura 5 (Theodoro, 1847)

A divisa da freguesia de São Miguel das Almas também é descrita por Theodoro em seu relatório. Segundo o relato, os limites da freguesia não são claros para o próprio pároco. Ao norte, não é clara a divisa com a freguesia de Ponte Nova, já ao sul, sabe-se somente que as divisas cortam os rios da Glória e Carangola, porém impossível definir claramente os limites com a freguesia de São Paulo. O limite da freguesia de São Miguel das Almas também é confuso na divisa com Campos (província do Rio de Janeiro), porém segundo Theodoro, as pessoas que habitavam próximo a cabeceira do Rio Preto pertenciam a freguesia de São Miguel das Almas, sendo aquele local pertencente a então freguesia (Theodoro, 1847).

O município do Presídio de acordo com a demarcação do Theodoro, apresentava uma extensão de aproximadamente $9.814 \mathrm{~km}^{2}$, sobrepondo esta área sobre o ordenamento atual dos municípios, nota-se que equivale a área de 50 municípios aproximadamente.

A demarcação do município do Presídio é confusa principalmente na divisa com a província do Rio de Janeiro. A divisa entre as províncias ocorre através de Presídio e Campos, e segundo Theodoro os limites consistem em seguir pela barra do Rio Pomba, os limites não são bem definidos, e seguem até cortar o Rio Muriaé e chegar a serra do Rio Preto. Após este trecho já se encontra os limites do Presídio com a província do Espírito Santo, onde a divisa segue em todo seu trecho pela Serra dos Pilões (Theodoro, 1847). 
Figura 6:Extensão territorial do município do Presídio em 1847 sobreposto ao ordenamento atual dos municípios.
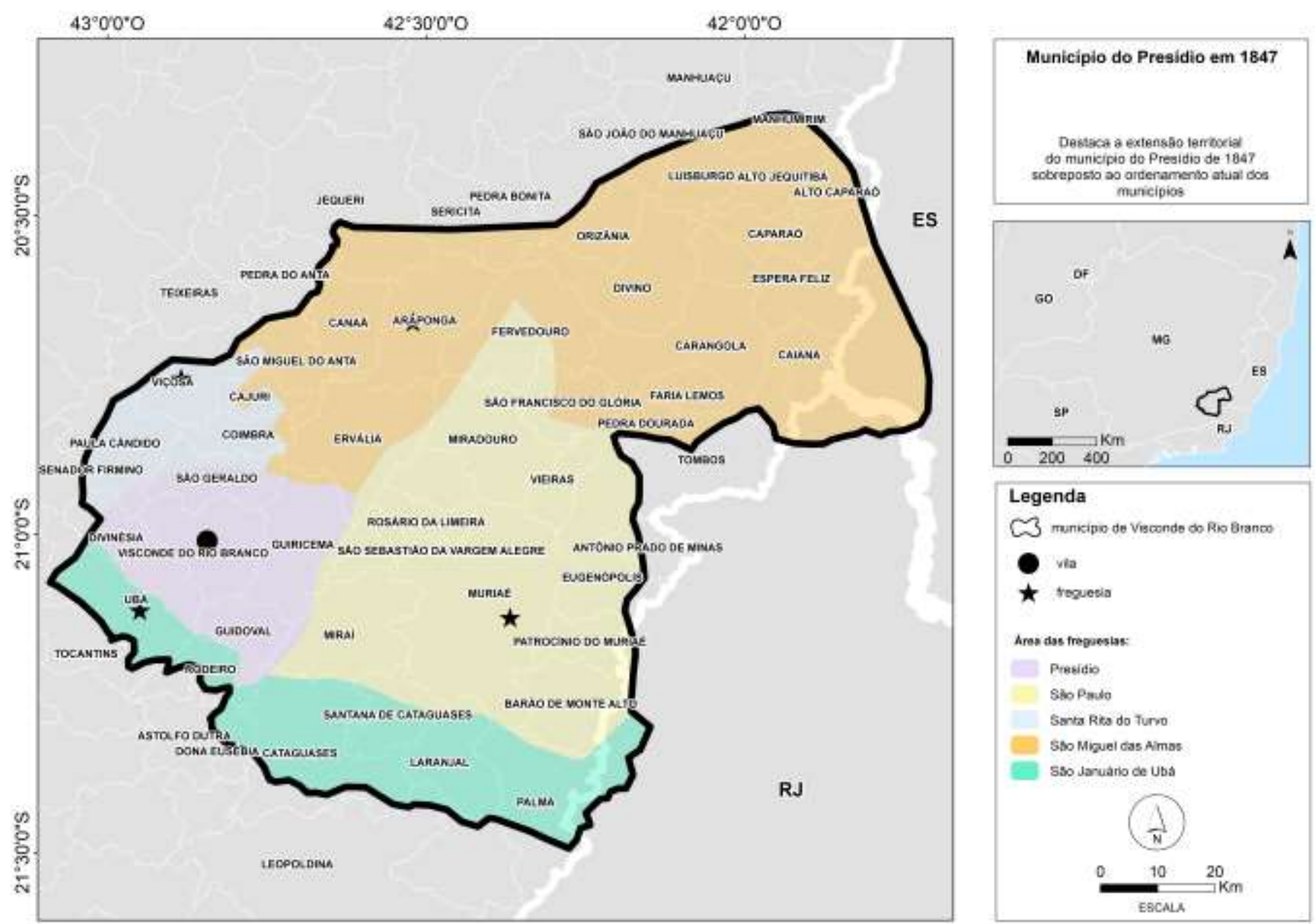

Fonte: Autores (2021).

\section{Considerações Finais}

Diante dos resultados apresentados, destaca-se inicialmente que os estudos sobre o ordenamento territorial dos municípios são complexos. Os estudos nesse campo envolvem diferentes áreas de pesquisas e ciências, exemplos são as pesquisas históricas, análise de mapas antigos e as leituras diversas que foram necessárias para o desenvolvimento da pesquisa. A História, a Cartografia e o Direito estão presentes para um estudo Geográfico, na medida que se analisa a construção do território.

O fato do poder eclesiástico estar presente ao longo do período colonial e imperial no ordenamento do território gerou ainda mais incongruência em estabelecer qualquer possibilidade de organização precisa. A dificuldade existente em traçar limites precisos para os municípios, somada a sobreposição do poder eclesiástico na divisão do território, e o fato dos limites das freguesias não serem claros, demonstram como o ordenamento territorial dos municípios mineiros eram confusos.

Em relação ao mapa histórico utilizado, destaca-se a importância da cartografia histórica em pesquisas que adentram ao campo da geografia histórica. Os mapas históricos de uma maneira geral contam com diversas informações relevantes que contribuem para a pesquisa. Os mapas históricos foram criados sem auxílio da tecnologia atual, o que lhe confere distorções de posicionamento espacial, porém através do geoprocessamento, utilizando pontos de controle para georreferenciar o mapa, foi possível estabelecer um posicionamento adequado e utilizar suas informações. Os procedimentos metodológicos adotados podem ser utilizados em outras pesquisas no campo da geografia histórica e com outros mapas históricos, para isso é 
necessário encontrar pontos de mesmas coordenadas geográficas no mapa antigo e em um mapa atual georreferenciado.

O mapa e o relatório de João José da Silva Theodoro foi muito representativo para demonstrar como os limites dos municípios não eram claros e como a sobreposição de poder administrativo e eclesiástico dificultavam a organização do território no século XIX. Silva Theodoro detalhou o seu trabalho de mapeamento, evidenciando que até mesmo para quem vivia naquele período e buscasse mapear o ordenamento territorial dos municípios encontraria dificuldade. Além disso o mapa vetorizado possibilitou representar como o espaço se organizava no século XIX, foi possível constatar a divisão do território em municípios com as suas sedes (vilas), e esses municípios subdivididos em freguesias, e essas freguesias compostas de outros curatos e capelas.

Por fim o estudo sobre ordenamento territorial é um tema ainda a ser aprofundado, o presente trabalho ao adotar Visconde do Rio Branco como área de estudo contribuiu com a história de construção e consolidação do ordenamento territorial do próprio município, e também dos demais municípios que pertenciam ao seu território antes de se desmembrarem.

\section{Referências}

Andrade, M. C. (2004). A questão do território no Brasil. (2a ed.), HUCITEC.

Brasil (1891). Constituição da República dos Estados Unidos do Brasil: 24 de fevereiro de 1891. Câmara dos Deputados, Brasília. <http://www2.camara.leg.br/atividade-legislativa/legislacao/Constituicoes_Brasileiras/anteriores.html>.

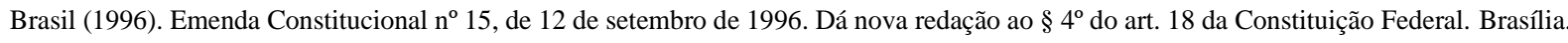

Carneiro, P. A., \& Matos, R. E. (2010). Geografia histórica da ocupação da zona da mata mineira: acerca do mito das "áreas proibidas". Anais do Seminário de Diamantina.

Carneiro Filho, R. (2009). Jornalismo Literário - Livro reportagem: origens, transição e mercado. 2009. 140 f. Dissertação (Mestrado) - Curso de Comunicação Social, Universidade Presidente Antônio Carlos, Ubá, 2009.

Carrara, A. A. \& Machado, P. J. O. (2019). Delimitação territorial dos municípios brasileiros no século XIX: um desafio metodológico. Locus: Revista de História, Juiz de Fora, 25(1), 20-36.

Carrara, A. A. \& Machado, P. J. O. (2020). Ordenamento territorial dos municípios brasileiros: minas gerais, séculos XVIII-XIX. Almanack, Guarulhos, 24.

Castro, J. F. M. (2017). Geoprocessamento de mapas de Minas Gerais nos séculos XVII-XIX. Editora PUC Minas.

Chaves, E. R. (2013). The founding of villages in Minas Gerais in the beginning of the monarchy in Brazil: the North of the province. Varia Historia, 29(51), $817-845$.

Colavite, A. P \& Barros, M. V. F. (2009). Geoprocessamento Aplicado a Estudos do Caminho de Peabiru. Revista da ANGEPE, 5 , 86 - 105.

Corrêa, D. C. (2008). Cartografia Histórica do Rio de Janeiro: Reconstituição Espaço-Temporal do Centro da Cidade. Universidade Federal do Rio de Janeiro, Programa de Pós-Graduação em Geografia, Rio de Janeiro.

Costa, Joaquim Ribeiro. (1997). Toponímia de Minas Gerais. BDMG Cultural.

Fonseca, C. D. (2011). Arraiais e vilas d'el rei: espaço e poder nas Minas setecentistas. Tradução de Maria Juliana Gambogi Teixeira e Cláudia Damasceno Fonseca. Belo Horizonte: UFMG. 731. (Humanitas). < http://books.scielo.org/id/d55c7/pdf/fonseca 9788542303070.pdf>.

Haesbaert, R. (2007). Território e multiterritorialidade: um debate. Geographia, 17(9), 19-46, 2007. https://periodicos.ufsm.br/geografia/article/view/22589.

Machado, P. J. O. (2012). Diagnóstico ambiental e ordenamento territorial: instrumento para a gestão da Bacia de Contribuição da Represa de Chapeu D’uvas/MG. Niterói: UFF.

Martins, L. U. S. \& Soares, R. V. (2016). Comarcas de Minas. Imprensa Oficial de Minas Gerais.

Martins, P. A. \& Silva, L. F. C. F. (2014). Panorama das Pesquisas com Sistemas de Informações Histórico-Geográficas no Mundo e Suas Relações com a Geografia, História e Cartografia Histórica. Revista Brasileira de Cartografia - (63/03), 485 - 498.

Marx, M. (1991). Cidade No Brasil Terra De Quem? Editora da Universidade de São Paulo. 141 p.

Mata, S. da. (2002). Chão de Deus: catolicismo popular, espaço e proto-urbanização em

Minas Gerais, Brasil. Séculos XVIII-XIX. Berlim: Wiss. Verl. Berlin, 304 p.

Minas Gerais (1853). assembléia legislativa provincial. lei nº 654, de 1853. transfere a sede dos municípios do presídio, e januária, e da freguesia de são miguel do jequitinhonha para outros lugares, cria novas freguesias e distritos, e contém outras disposições acerca de limites de diversas paróquias, e distritos, como nela se declara. Lei N. 654 de 17 de Junho de 1853. Ouro Preto: Tipografia do Bom Senso, 167-170. 
Research, Society and Development, v. 10, n. 2, e50710212720, 2021

(CC BY 4.0) | ISSN 2525-3409 | DOI: http://dx.doi.org/10.33448/rsd-v10i2.12720

Minas Gerais (1869). Assembléia legislativa provincial. Lei no 1573, de 1869. Transfere a sede do município do ubá para a freguesia do presídio. Lei N. 1.573 de 22 de Julho de 1868. Ouro Preto: Tipografia de J. F. de Paula Castro, p. 96.

Minas Gerais (1897). X - Relação das cidades, villas e povoações da provincia de minas geraes com declaração do numero de fogo de cada uma (1830). Ouro Preto: Imprensa Oficial de Minas Gerais. http://www.siaapm.cultura.mg.gov.br/modules/rapm/brtacervo.php?cid=41.

Minas Gerais (1927). Secretaria da Agricultura. Album Chorographico Municipal do Estado de Minas Geraes. Imprensa Official.

Minas Gerais. (1995). LEI COMPLEMENTAR № 37/1995 de 18/01/1995. https://leisestaduais.com.br/mg/lei-complementar-n-37-1995-minas-gerais-dispoe-

Orea, D. G. (2008). Ordenación Territorial. (2a ed.). Ediciones Mundi-Prensa.

Pinto, T. A. (2002). Xopotó dos Coroados: cartilha. Imprensa Oficial de Minas Gerais, 40 p.

Raffestin, C. (1993). Por uma geografia do poder. Ed. Ática.

Reis, E.; Pimentel, M.; \& Alvarenga, A. I. (2011). Áreas mínimas comparáveis para os períodos intercensitários de 1872 a 2000. http://www.ipeadata.gov.br/doc/AMC-1872-2000.doc

Seemann, J. (2005). A toponímia como construção histórico-cultural: o exemplo dos municípios do estado do Ceará. Vivência, 1(29), 207-224.

Theodoro, J. J. S. (1847). Relatório do tenente joão josé da silva theodoro. Typographia do Echo de Minas. 